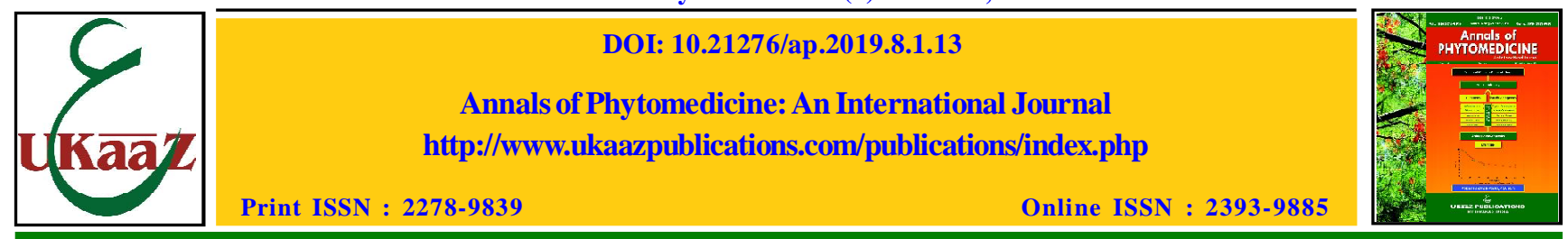

Original article

\title{
Immunopotentiating activity of hemiparasitic plants of family Viscaceae with special reference to Viscum angulatum Heyne ex DC.
}

\author{
Girija Kuttan and Ramadasan Kuttan* \\ Amala Cancer Research Centre, Amala Nagar, Thrissur-680555, Kerala, India
}

Received March 4, 2019: Revised April 25, 2019: Accepted April 28, 2019: Published online June 30, 2019

\begin{abstract}
The present study was carried out to evaluate immunopotentiating activity of hemiparasitic sub-herbs plants belongs to Viscaceae family. Aqueous extracts of selected six Viscum plants such as, Viscum orientale Wild (8 $\mathrm{mg} /$ $\mathrm{kg}$ body weight), Viscum nepalense Spiens $(8 \mathrm{mg} / \mathrm{kg}$ body weight), Viscum ramosissimum Well $(8 \mathrm{mg} / \mathrm{kg}$ body weight), Viscum angulatum Heyneex DC (16 mg/kg body weight), Viscum capitallatum $\mathrm{Sm}(8 \mathrm{mg} / \mathrm{kg}$ body weight) and Viscum trilobatum Talbot $(8 \mathrm{mg} / \mathrm{kg}$ body weight) were injected intraperitoneally for 5 consecutive days to $\mathrm{Balb} / \mathrm{c}$ mice and to determine the haematological parameters, body weight, lymphoid organ weight, bone marrow cellularity and $\alpha$-esterase positive cells and compared with controls treated with plain water. Non-toxic $V$. angulatum extract $(16 \mathrm{mg} / \mathrm{kg})$ was administered to Balb/c mice (5 doses) and its effect on antibody titre, antibody forming cells, lymphoid cell proliferation, cytotoxic T lymphocyte generation and interferon $\gamma$ (IFN- $\gamma$ ) and interleukin 2 (IL-2) levels were determined. Results indicated that there was a significant increase in white blood cells (WBC), lymphoid organ weight, bone marrow cellularity and $\alpha$-esterase positive cells after intraperitoneal administration. Administration of $V$. angulatum extract increased antibody titre, antibody forming cells, proliferation of lymphoid cells, stimulated cytotoxic T lymphocyte as well as increased levels of IL-2 and IFN- $\gamma$. Results indicated a stimulation of immunological parameters in mice after intraperitoneal injection of aqueous extracts of plants belonging to the family Viscaceae.
\end{abstract}

Keywords: Viscum album, Viscum angulatum, immune stimulation, cancer treatment, cytokines

\section{Introduction}

Role of immunity in the cancer development and progression is known (Zammaron and Chen, 2011). Cancer produces lowering of immunity and immune suppression has been known to be a stimulating factor in the progression to malignancy (Finn, 2012). Drugs that can increase the immunity are found to be useful in reducing cancer development (Newman et al., 2003). Several drugs including synthetic as well as plant based drugs were found to stimulate immunity, thereby will be useful in the cancer treatment (Polu et al., 2015). Plants such as Panox ginsieng, Tinospora cordifolia, and Withania somnifera, etc., are known to have significant immune stimulating activity (Ochwang et al., 2014). Moreover, herbal preparations such as Rasayanas are found to stimulate immunity in normal and cancer patients and are useful in prophylaxis and treatment of cancer (Vayalil et al., 2002). Rasayanas are also known to reduce the side effects of chemotherapy and radiation through immune stimulation (Vayalil et al., 2002). Viscum album Linn. is a hemiparasitic plant, widely present in Europe. An injectable preparation, Iscador, prepared from this plant was found to be useful in cancer treatment and is being practiced in many parts of Europe (Leroi, 1975). Active constituents of Iscador included a lectin (Franz, 1986), viscotoxins (Samuelson and Petterson, 1971), polysaccharides (Jordan and

\footnotetext{
Author for correspondence: Dr. Ramadasan Kuttan Professor, Amala Cancer Research Centre, Amala Nagar, Thrissur680555, Kerala, India

E-mail: amalacancerresearch@gmail.com

Tel.: +91-9447123071
}

Copyright () 2019 Ukaaz Publications. All rights reserved.

Email: ukaaz@yahoo.com; Website: www.ukaazpublications.com
Wagner, 1986) as well as a peptide of 5000 molecular weight (Kuttan et al., 1988). Iscador acts not only by its cytotoxic activity but also by stimulating immunity (Kuttan and Kuttan, 1992).

Not much work has been done in other Viscum species. Recently, we had reported the tumor reducing activity of six plants of Viscum species present in the Western Ghats of India (Kuttan et al., 2017). However, out of six plants, five of them such as Viscum orientale Wild, Viscum nepalense Spiens, Viscum ramosissimum Well, Viscum capitallatum Sm, Viscum trilobatum Talbot were found to be highly toxic. At non-toxic dosage, they could reduce the transplanted tumors in animals (Kuttan et al., 2017). In the present study, we have studied the immunostimulating activity of these Viscum species and special emphasis has been given to the non-toxic plant, V. angulatum.

\section{Materials and Methods}

\subsection{Animals}

Balb/c mice (male, 4-6 week old, 20-25 g.b.wt) were obtained from Small Animal Breeding Station, Kerala Veterinary and Animal Sciences University, Thrissur, Kerala, India. The animals were kept in ventilated cages in air-controlled room and fed with mouse chow(Krish Scientific Shopee, Bangalore, India) and water ad libitum. All animal experiments were performed as per the instructions prescribed by the Committee for the Purpose of Control and Supervision of Experiments on Animals (CPCSEA) (N0.149/PO/ Rc/S/1999/CPCSEA), Ministry of Environment and Forest, Government of India, and implemented through the Institutional Animal Ethical Committee of Amala Cancer Research Centre. 


\subsection{Chemicals}

RPMI medium was purchased from Hi-media, Mumbai, India. ParaRosaniline and $\alpha$-napthyl acetate were obtained from Loba Chemie, Mumbai. Harri's hematoxylin was purchased from Glaxo, Mumbai, India. Lypopolysaccharids, Phytohaemagglutinin and Pokeweed mitogen were purchased from Difco Laboratories, New Delhi, India. Conconavaline A was obtained from Sigma (St. Louis, MO). Radioactive $\left({ }^{3} \mathrm{H}\right)$ - thymidine was purchased from the Board of Radiation and Isotope Technology, Mumbai, India. Elisa Kits for IL-2 and IFN- $\gamma$ were purchased from Pierce Biotechnology, USA. All other chemicals used were of analytical reagent grade.

\subsection{Collection of plants and their identification}

Hemiparasitic sub-herbs in the family Viscaceae were collected as per good collection practice from Chammundi Hills and Bandipur forest area, Mysore as well as from Belgam, India. Botanical identity was confirmed by Dr. Sivamurthy. G. R, Professor, Department of Botany, JSS College for Women, Saraswathypuram, Mysore after comparing with voucher specimens. The species of plants and their host trees are given in Table1.

Table 1: Names of Viscum species collected from Western Ghats and their host plants

\begin{tabular}{|l|l|}
\hline Plants & Host tree \\
\hline Viscum orientale Wild & Pongamia pinnata L. \\
Viscum nepalense Spiens & Zizyphus oenoplea (L.) Miller \\
Viscum ramosissimum Well & Ficus bengalensis L. \\
Viscum angulatum Heyne ex DC & Schrebera swietenioides Roxb. \\
Viscum capitallatum Sm & Terminalia tomentosa Roxb. \\
Viscum trilobatum Talbot & Magnifera indica L. \\
\hline
\end{tabular}

\subsection{Preparation of aqueous extract}

Plants were washed in running water, rinsed with autoclaved double distilled water, air dried and powdered. Aqueous extracts of each plant were prepared by mixing $10 \mathrm{~g}$ of plant powder with $100 \mathrm{ml}$ of autoclaved double distilled water and stirred overnight. The supernatant obtained by centrifugation was dried by lyophilization.

\subsection{Determination of the effect of Viscaceae plant extract on the haematological parameters and body weight}

Mice were grouped into seven ( $\mathrm{n}=8$ /group). Group I animals kept as untreated control, were given plain water $(0.5 \mathrm{ml})$. Group II to VI animals were treated intraperitoneally with 5 doses of aqueous extracts of V.orientale, V.nepalense, V.ramosissimum, V.capitellatum, V.trilobatum $(8 \mathrm{mg} / \mathrm{kg}$ b.wt) and group VII with V.angulatum (16 $\mathrm{mg} / \mathrm{kg}$. b.wt) aqueous extract. These doses were fixed after studying the toxicity profile of the extracts (Kuttan et al., 2017). On $6^{\text {th }}$ day, blood was collected from the caudal vein of all animals and various parameters such as, total white blood cells (WBC) count (Hemocytometer), differential count (Leishman's stain) and hemoglobin level (Cyanmethaemoglobin method) (Cheesbrough and McArthur, 1976) were measured. The body weight was recorded prior to the administration of Viscaceae plant extract and continued every third day thereafter for one month.

\subsection{Determination of the effect of Viscaceae plant extract on the lymphoid organ weight}

Mice ( $\mathrm{n}=8 /$ group) were divided into seven groups and treated with aqueous extracts Viscum plants as described above. Body weight of animals were recorded before sacrifice. All animals were sacrificed $24 \mathrm{~h}$ after the last dose of Viscum extract administration. Weight of the lymphoid organs such as, spleen and thymus were recorded and expressed as relative organ weight.

\subsection{Determination of the effect of Viscaceae plant extract on the bone marrow cellularity and $\alpha$-esterase positive cells}

Bone marrow cells from the femurs of above experimental animals were collected and made into single cell suspension and the cell number was determined using haemocytometer (Sredni et al., 1992) and expressed as million cells/ femur. A thin film of bone marrow cells was prepared on clean glass slide and the number of $\beta$-esterase positive cells was determined by azo-dye coupling method (Cheesbrough and McArthur, 1976). Number of $\alpha$-esterase positive cells was expressed out of 4000 cells.

\subsection{Determination of the effect of $V$. angulatum on circulating antibody titre}

Mice ( $\mathrm{n}=8$ /group) were divided into two groups. Group I animals were kept as normal without any treatment. Group II animals were treated intraperitoneally with $V$. angulatum extract $(16 \mathrm{mg} / \mathrm{kg}$. b. wt) for 5 consecutive days. All the animals were immunized with sheep red blood cells $(\mathrm{SRBC})\left(2.5 \times 10^{\circ}\right.$ cells $/ 0.1 \mathrm{ml} / \mathrm{animals}$, intraperitoneal) after the last dose of test compound administration. Blood was collected from the caudal vein every $3^{\text {rd }}$ day after immunization with SRBC and continued for a period of 30 days. Serum was separated and heat inactivated at $56^{\circ} \mathrm{C}$ for $30 \mathrm{~min}$. Antibody titre was determined by haemagglutination assay of Singh et al. (1984) using SRBC as antigen.

2.9 Determination of the effect of $V$. angulatum extract on antibody producing cells (Plaque Forming Cells Assay) (PFC)

The experiment was set up as described in the previous experiment. The animals were sacrificed on different days starting from the $3^{\text {rd }}$ day after immunization up to $9^{\text {th }}$ day. Spleen was processed to single cell suspension and used for the determination of antibody producing cells by Jerne's plaque assay (Jerne and Nordin, 1963).

\subsection{Determination of the effect of $V$. angulatum aqueous extract on lymphoid organ proliferatiom}

Mice were divided into two groups ( $\mathrm{n}=4$ /group). Group I animals were kept as normal control and Group II animals were treated with $V$. angulatum extract $(20 \mathrm{mg} / \mathrm{kg}$.b.wt) intraperitoneally for 5 consecutive days. Animals were sacrificed $24 \mathrm{~h}$ after last dose of the test compound administration. The spleen, thymus and bone marrow from femur were collected aseptically and processed to single cell suspension. Triplicate cultures were set to determine the proliferation in the presence and absence of various mitogens such as Concanavaline (Con-A)-10 $\mu \mathrm{g} / \mathrm{ml}$, Phytohaemagglutinin (PHA)$2.5 \mu \mathrm{g} / \mathrm{ml}$, Lycopolysaccharides (LPS) $-10 \mu \mathrm{g} / \mathrm{ml}$ and Pokeweed mitogen (PWM)-10 $\mu \mathrm{g} / \mathrm{ml}$ by thymidine incorporation assay (Justo et al., 2003).

\subsection{In vivo determination of the effect of $V$. angulatum extract} on the cytotoxic $T$ lymphocyte (CTL) generation

Four groups of mice ( $n=10 /$ group) were used (system A). Group I received EL4 cells (intraperitoneal) (purchased from National Cell Science Centre, Pune) alone $\left(5 \times 10^{5} / 0.1 \mathrm{ml}\right)$. Group II animals 
received $V$. angulatum extract $(16 \mathrm{mg} / \mathrm{kg} \mathrm{b} \mathrm{wt})$ for 5 consecutive days prior to EL4 administration. Group III animals received EL-4 cells incubated with normal spleen cells $(0.2 \mathrm{ml})$ from the BALB/c. Group IV animals received EL-4 cells incubated with spleen cells from V.angulatum extract treated alloimmunized mice. CTL activity was determined by Winn's neutralization assay (Winn, 1961). All the animals were observed for their survival. The survival time of treated animals were compared with that of animals which received tumour cells alone.

\subsection{Determination of the effect of Viscaceae plant extract on interleukin 2 (IL-2) and interferon- $\gamma($ IFN- $\gamma$ ) production in normal and tumour bearing animals}

Blood was collected from each animal 2 days after the last dose of $V$. angulatum administration, and the levels of the IL-2 and IFN- $\gamma$ were assayed using an ELISA kit purchased from Pierce Biotechnology, (USA). The manufacturer's protocol was followed to estimate the level of cytokines.

\subsection{Statistical analysis}

Values are expressed as Mean \pm standard deviation. The statistical significance was compared between control and experimental groups by one-way analysis of variance (ANOVA), followed by appropriate post hoc test (Dunnett multiple comparison test) using Graphpad software. Data of extract-treated animals were compared with nontreated animals.

\section{Results}

\subsection{Effect of Viscum extracts on haematological parameters and body weight}

The total WBC count in normal BALB/c mice was increased by the administration of all the six Viscaceae plant extracts (Figure 1). The maximum WBC count of $11216 \pm 338$ cells $/ \mathrm{mm}^{3}, 10025 \pm 348$ cells/ $\mathrm{mm}^{3}$ and $10016 \pm 341 \mathrm{cells} / \mathrm{mm}^{3}$ was obtained on $12^{\text {th }}$ day after the administration of $V$. angulatum $(16 \mathrm{mg} / \mathrm{kgb} . \mathrm{wt}), V$. ramosissimum ( $8 \mathrm{mg} / \mathrm{kg}$ b.wt) and Viscum nepalense $(8 \mathrm{mg} / \mathrm{kg}$ b.wt), respectively which was higher than untreated control. The total WBC count of remaining three Viscaceae plant extracts were also increased when compared to the untreated ones. The untreated control animals maintained the normal total WBC count during the experimental time. Among these six, Viscaceae plant extracts, V. angulatum treated mice showed maximum WBC count when compared to the other plant extracts. A normal increase in the body weight was shown by the Viscum extract treated animals, however, it was not significant (data not shown). There was no significant difference in the ratio of lymphocytes to neutrophils, (data not shown) as well as hemoglobin level, non-significant (data not shown) after treatment with test compounds.

\subsection{Effect of Viscum extracts on lymphoid organ weight}

Effect of Viscaceae plant extracts on relative organ weight of thymus and spleen is given in Table 2 . An increase $(p<0.05)$ in the weight of thymus $(0.14 \pm 0.002 \mathrm{~g} / 100 \mathrm{~g}$ b.wt $)$ and spleen $(0.413 \pm 0.016 \mathrm{~g} /$ $100 \mathrm{~g} \mathrm{~b}$. wt) was found in $V$. angulatum treated animals when compared to normal (thymus: $0.12 \pm 0.015 \mathrm{~g} / 100 \mathrm{~g} \mathrm{~b}$. wt; spleen $0.39 \pm 0.013 \mathrm{~g} / 100 \mathrm{~g}$ b.wt) animals. There was no significant change in the weight of other vital organs such as liver, kidney, and lung (data not shown).

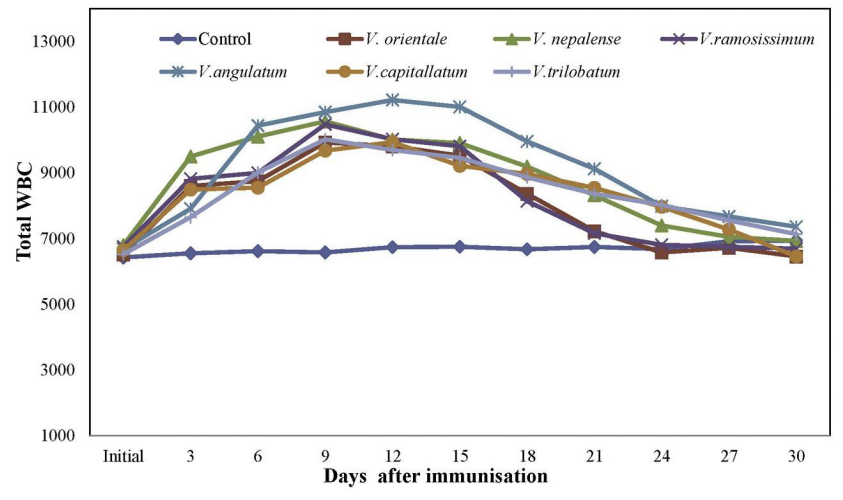

Figure 1: Effect of adminstration of Viscum extracts on total WBC in mice. Values are means of eight replicates per group.

Table 2: Effect of administration of Viscum extracts on lymphoid organ weights in mice

\begin{tabular}{|l|c|c|}
\hline \multirow{2}{*}{ Group } & \multicolumn{2}{|c|}{$\begin{array}{c}\text { Relative organ weight } \\
\text { (g/100 g body weight) }\end{array}$} \\
\cline { 2 - 3 } & Thymus & Spleen \\
\hline $\begin{array}{l}\text { Normal } \\
\begin{array}{l}\text { Viscum orientale } \\
(8 \mathrm{mg} / \mathrm{kg} \text { b.wt })\end{array}\end{array}$ & $0.12 \pm 0.015$ & $0.39 \pm 0.013$ \\
$\begin{array}{l}\text { Viscum nepalense } \\
(8 \mathrm{mg} / \mathrm{kg} \text { b.wt) }\end{array}$ & $0.13 \pm 0.003$ & $0.40 \pm 0.019$ \\
$\begin{array}{l}\text { Viscum ramosissimum } \\
(8 \mathrm{mg} / \mathrm{kg} \text { b.wt) }\end{array}$ & $0.13 \pm 0.003$ & $0.39 \pm 0.006$ \\
$\begin{array}{l}\text { Viscum angulatum } \\
(16 \mathrm{mg} / \mathrm{kg} \text { b.wt })\end{array}$ & $0.14 \pm 0.002 *$ & $0.413 \pm 0.016 *$ \\
$\begin{array}{l}\text { Viscum capitellatum } \\
(8 \mathrm{mg} / \mathrm{kg} \text { b.wt) }\end{array}$ & $0.13 \pm 0.007$ & $0.40 \pm 0.01$ \\
$\begin{array}{l}\text { Viscum trilobatum } \\
\text { (8 mg / kg b.wt) }\end{array}$ & $0.13 \pm 0.005$ & $0.39 \pm 0.027$ \\
\hline
\end{tabular}

Values are Mean \pm standard deviation of eight replicates per group. Values were statistically analyzed using one-way ANOVA, followed by Dunnett multiple comparison test. ns $=$ Not significant $(p>0.05)$, ${ }^{*} p<0.05$ significant.

Table 3: Effect of administration of Viscum extracts on bone marrow cellularity and $\alpha$-esterase positive cells

\begin{tabular}{|c|c|c|}
\hline Group & $\begin{array}{c}\text { Bone marrow } \\
\text { cellularity } \times 10^{6} \\
\text { /femur }\end{array}$ & $\begin{array}{c}\text { No. of } \alpha \text {-esterase } \\
\text { positive cells } \\
/ 4000 \text { cells }\end{array}$ \\
\hline Normal & $16.5 \pm 1.87$ & $780.16 \pm 15.96$ \\
\hline $\begin{array}{l}\text { Viscum orientale } \\
\text { ( } 8 \mathrm{mg} / \mathrm{kg} \text { b.wt })\end{array}$ & $18 \pm 40^{\mathrm{ns}}$ & $858.5 \pm 8.14 *$ \\
\hline $\begin{array}{l}\text { Viscum nepalense } \\
(8 \mathrm{mg} / \mathrm{kg} \text { b.wt })\end{array}$ & $24 \pm 2.83 * *$ & $1042.17 \pm 54.01 * *$ \\
\hline $\begin{array}{l}\text { Viscum ramossimum } \\
(8 \mathrm{mg} / \mathrm{kg} \text { b.wt })\end{array}$ & $20.17 \pm 2.40^{*}$ & $999.67 \pm 32.9 * *$ \\
\hline $\begin{array}{l}\text { Viscum angulatum } \\
\text { (16 } \mathrm{mg} / \mathrm{kg} \text { b.wt) }\end{array}$ & $28.16 \pm 2.86 * *$ & $1127.83 \pm 101.7 * *$ \\
\hline $\begin{array}{l}\text { Viscum capitellatum } \\
(8 \mathrm{mg} / \mathrm{kg} \mathrm{b.wt})\end{array}$ & $21.16 \pm 1.94 * *$ & $963.17 \pm 37.73 * *$ \\
\hline $\begin{array}{l}\text { Viscum trilobatum } \\
(8 \mathrm{mg} / \mathrm{kg} \mathrm{b.wt)}\end{array}$ & $19.17 \pm 2.14^{\mathrm{ns}}$ & $873.33 \pm 27.19 *$ \\
\hline
\end{tabular}

Values are the Mean \pm standard deviation of eight replicates per group. Values were statistically analyzed using one-way ANOVA, followed by Dunnett multiple comparison test. ns $=$ Not significant $(p>0.05)$, ${ }^{*} p<0.05,{ }^{* *} p<0.01$ significant. 
3.3 Effect of Viscum extracts on bone marrow cellularity and $\alpha$-esterase positive cells.

The effect of Viscaceae plant extracts on the bone marrow cellularity and $\alpha$-esterase positive cells is given in the Table 3 . Administration of $V$. angulatum, $V$. nepalense and $V$. capitellatum significantly increased $(p<0.01)$ the bone marrow cellularity compared to normal. The number of $\alpha$-esterase positive cells were also increased significantly $(p<0.01)$ in $V$. angulatum, $V$. nepalense, V. capitellatum and V. ramosissimum administered animals compared to normal.

\subsection{Effect of $V$. angulatum on antibody production}

The enhancement of total antibody production by the administration of $V$. angulatum $(16 \mathrm{mg} / \mathrm{kg}$ b.wt) is shown in the Figure 2. The maximum antibody titre value of 512 was observed on $15^{\text {th }}$ day after immunization and the level was maintained up to $18^{\text {th }}$ day. The untreated control animals showed a maximum antibody titer value 64 on $12^{\text {th }}$ day after antigen administration.

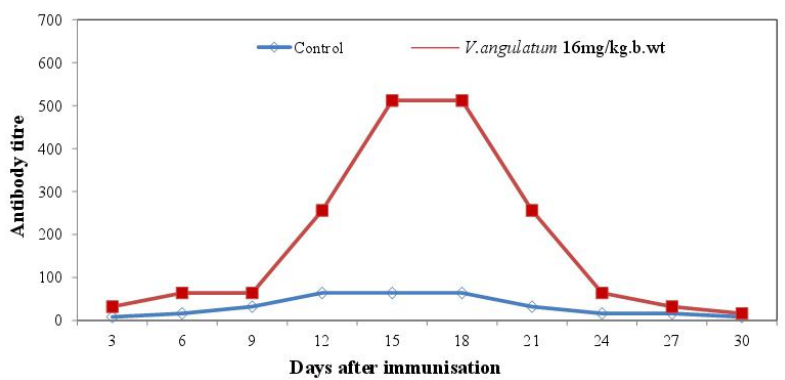

Figure 2: Effect of administration of V. angulatum extract on antibody production Values are the means of eight replicates per group.

\subsection{Effect of $V$. angulatum on antibody producing cells}

Administration of Viscum angulatum significantly enhanced the number of antibody producing cells in the spleen. The maximum number of plaque forming cells (PFC) was observed in $V$. angulatum $(210.83 \pm 12.58 \mathrm{PFC} /$ million spleen cells $)$ treated animals on $6^{\text {th }}$ day after immunization while the vehicle control animals showed only $150.83 \pm 10.10 \mathrm{PFC} /$ million cells on the same day (Figure 3 ).

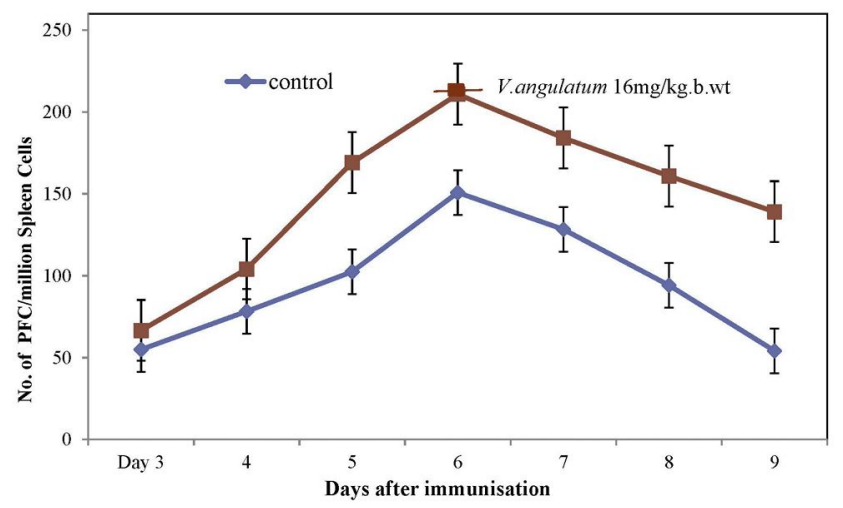

Figure 3: Effect of administration of $V$. angulatum extract on antibody producing cells. Values are the means of eight replicates per group.

\subsection{Effect of $V$. angulatum on lymphoid organ proliferation}

Effect of V. angulatum on the lymphoid organ proliferation is given in Tables 4ABC. Significant enhancement lymphoid organ proliferation as seen from the mitogenic potential of various mitogens such as Con-A, PHA, PWM and LPS on spleen, thymocytes and bone marrow cell proliferation observed in $V$. angulatum treated group compared to normal group as well as mitogen alone treated group.

Table 4: Effect of $V$. angulatum administration on lymphoid organ proliferation

\section{A. Proliferation of spleenocytes}

\begin{tabular}{|l|c|c|c|c|c|}
\hline Group & No mitogen & Con A & PHA & \multicolumn{1}{|c|}{ LPS } & PWM \\
\hline Control & $1039 \pm 100.6$ & $3301.3 \pm 140.9$ & $3126.3 \pm 103.7$ & $2646.3 \pm 150$ & $2878.5 \pm 148$ \\
$\begin{array}{l}\text { Viscum angulatum } \\
(20 \mathrm{mg} / \mathrm{kg} \text { b.wt })\end{array}$ & $2516.8 \pm 75.6^{* * *}$ & $5495.3 \pm 128.5^{* * *}$ & $5440.5 \pm 177.8^{* * * *}$ & $5448.2 \pm 129.3^{* * * *}$ & $4659 \pm 57^{* * *}$ \\
\hline
\end{tabular}

B. Proliferation of Thymocytes

\begin{tabular}{|l|c|c|c|c|}
\hline Group & No mitogen & Con A & PHA & PWM \\
\hline Control & $1156.3 \pm 50.5$ & $2411.3 \pm 92.4$ & $2301.3 \pm 129.4$ & $1548.7 \pm 79.5$ \\
$\begin{array}{l}\text { Viscum angulatum } \\
(20 \mathrm{mg} / \mathrm{kg} \text { b.wt })\end{array}$ & $3320.8 \pm 155.2 * * *$ & $5340.8 \pm 119.9 * * *$ & $5841 \pm 131.9 * * *$ & $4294.7 \pm 226.3 * * *$ \\
\hline
\end{tabular}

C. Proliferation of bone marrow cells

\begin{tabular}{|l|c|c|c|c|c|}
\hline Group & No mitogen & Con A & PHA & LPS & PWM \\
\hline Control & $1136.5 \pm 95.1$ & $1172.3 \pm 122.3$ & $3559 \pm 98.6$ & $3271.5 \pm 135.6$ & $2162 \pm 130$ \\
$\begin{array}{l}\text { Viscum angulatum } \\
(20 \mathrm{mg} / \mathrm{kg} \mathrm{B.wt)}\end{array}$ & $1934.7 \pm 88.3 * * *$ & $2194 \pm 170^{* * *}$ & $4226.3 \pm 150.3 * * *$ & $3366.8 \pm 142 * * *$ & $2388.5 \pm 106.7 * * *$ \\
\hline
\end{tabular}

Values are expressed as cpm

Values are Mean \pm standard deviation of four replicates per group for untreated control and Viscum angulatum treated samples with and without mitogen $* * * p<0.001 \quad * * p<0.01$. 
Table 5: Effect of Viscum angulatum on in vivo CTL generation and survival of animals

\begin{tabular}{|l|c|c|}
\hline Groups & Mean survival days & \% Increase in life span \\
\hline EL-4 alone & $35.5 \pm 2.31$ & - \\
EL-4+ Viscum angulatum extract & $43.5 \pm 1.71$ & 22.54 \\
EL-4+ normal alloimmunized effector cell & $39.5 \pm 2.13$ & 11.26 \\
EL-4+ Viscum angulatum extract + treated alloimmunized spleen cells & $46.75 \pm 1.69$ & 31.69 \\
\hline
\end{tabular}

Values are Mean \pm standard deviation of ten replicates per group.

Table 6. Effect of Viscum angulatum extracts on IL-2 and IFN- $\gamma$ production in EL-4 cells

\begin{tabular}{|l|c|c|}
\hline Groups & IL-2 $(\mathrm{pg} / \mathrm{ml})$ & IFN- $\gamma(\mathrm{pg} / \mathrm{ml})$ \\
\hline Normal & $10.68 \pm 1.06$ & $2502.73 \pm 222.14$ \\
EL-4 alone & $5.44 \pm 0.88^{* * *}$ & $1128.86 \pm 127.98^{* * *}$ \\
EL-4 + Viscum angulatum extract & $12.5 \pm 1.51^{* * *}$ & $2461.97 \pm 158.22^{* * *}$ \\
EL-4 + normal cocultured spleen cells & $8.53 \pm 0.84 * *$ & $1271.16 \pm 101.67 * *$ \\
EL-4 + Viscum angulatum extract + treated cocultured cells spleen & $15.18 \pm 1.93^{* * *}$ & $2881.36 \pm 130.84^{* * *}$ \\
\hline
\end{tabular}

Values are Mean \pm standard deviation of four replicates per group $* * * p<0.001 * * p<0.01$.

\subsection{Effect of $V$. angulatum extract on cytotoxic $T$ lymphocytes} (CTL) generation and survival of animals

CTL action was calculated by Winn's neutralization assay from the number of days animals survived after injection of EL-4 cells. Animals injected only with EL-4 cells survived for 35.5 days. When the animals were treated with $V$. angulatum extract, survival was increased to 43.5 days $(22.54 \%)$. Induction of EL-4 cells with normal alloimmunised spleen cells increased the survival by 39.5 days while EL-4 cells treated with $V$. angulatum extract and alloimmunised cells increased the survival by 46.75 days, indicating increased CTL generation by treatment with $V$. angulatum extract (Table. 5).

\subsection{Effect of $V$. angulatum on interferon- $\gamma$ and interleukin-2 production}

The effect of $V$. angulatum on IFN- $\gamma$ and IL-2 production is presented in the given Table 6. Serum IL-2 level was significantly elevated in animals treated with $V$. angulatum $(12.5 \pm 1.51 \mathrm{pg} / \mathrm{ml})$ compared to normal animals $(10.68 \pm 1.06 \mathrm{pg} / \mathrm{ml})$. In tumour bearing control animals, IL-2 level was significantly reduced on day 6 after tumour induction $(8.53 \pm 0.84 \mathrm{pg} / \mathrm{ml})$, whereas treatment with $V$. angulatum promoted IL-2 production in tumour bearing animals to $15.18 \pm$ $1.93 \mathrm{pg} / \mathrm{ml}$.

The serum IFN- $\gamma$ level was also enhanced by the treatment with $V$. angulatum. In normal animals, the level of IFN- $\gamma$ was found to be $2461.97 \pm 158.22 \mathrm{pg} / \mathrm{ml}$ after administration with $V$. angulatum in comparison with the normal untreated animals $(2502.73 \pm 222.14$ $\mathrm{pg} / \mathrm{ml})$. IFN- $\gamma$ was found to be decreased in tumour bearing animals $(1271.16 \pm 101.67 \mathrm{pg} / \mathrm{ml})$ and decreased levels were significantly increased by the treatment with $V$. angulatum $(2881.36 \pm 130.84$ $\mathrm{pg} / \mathrm{ml}$ ) on the sixth day of tumour induction.

\section{Discussion}

Immunological activity of hemiparasitic plants extracts has been seldom studied. The only exception is $V$. album and an injectible preparation (Iscador) made from this extract is being used for cancer treatment. Iscador is reported to be cytotoxic and has immunomodulatory activity. Recently, we have reported the biological activity especially anticancer and anti-inflammatory activity of six plants from the family Viscaceae (Kuttan et al., 2017). However, except one plant, all the others are highly toxic to animals. Viscum angulatum was non-toxic and had significant anticancer activity against transplanted tumours and, hence this plant was further used for experimentation (Kuttan et al., 2017).

Initial studies using these plant extracts were carried out to determine the humoral immune responses. Administration of these plant extracts to animals increased haematological parameters such as total white blood cell count, lymphoid organ weight as well as bone marrow cellularity and $\alpha$-esterase positive cells. Further, studies were done using non-toxic extract prepared from V.angulatum. Administration of $V$. angulatum extract was found to increase the antibody production and increased antibody forming cells in mice, indicating the immunopotentiating activity of the extract. Administration of the extract to animals increased the proliferation of splenocytes, thymocytes and bone marrow cells. Moreover, administration of $V$. angulatum extract could significantly increase cytotoxic $\mathrm{T}$ lymphocyte generation and increased the survival of animals treated in EL-4 tumour cells and stimulated the production of interleukin 2 and interferon $\gamma$-production.

At present, there are only very few reports on the biological activities of Viscum species other than Viscum album. Antioxidant activity of V. orientale (Khatun et al., 2016), V. nepalenese (Murali et al., 2011) and $V$. capitallatum (Petrus, 2011) have been reported. Moreover, analgesic potential of $V$. capitallatum as well as diuretic action of $V$. angulatum and antinociceptive and CNS action of $V$. orientale has been reported (Jadhav et al., 2010). These studies indicate the potential of Viscum extracts during medical treatment. Active ingredients present in Viscum plants have not been fully identified. Since many of the Viscum species tested were found to be toxic, presence of toxic lectins could be expected in these plants.

Bioactive polyphenols have been reported from V.orientale. $V$. angulatum has been reported to have phenolic glycosides (Lin 
and Lin, 2002) and flavan glycosides (Asad et al., 2016) which may be responsible for its antitumour activities. Attenuation of expression of cytokines, oxidative stress and inflammation by phenolic acids has been reported (Yuvaraj etal., 2013). Further studies are needed to expose the biological activity of these plants and their active ingredients and mechanism of action.

\section{Conclusion}

Results indicated significant immunostimulatory activity of the extracts of plants belong to Viscaceae family as seen from haematological parameters, lymphoid organ weight, bone marrow cellularity, antibody production, antibody forming cells, lymphoid organ proliferation, cytotoxic $\mathrm{T}$ lymphocytic generation as well as increased Interleukin - 2 and Interferon $\gamma$ levels in mice. Out of six plant extracts tested, five of them were found to be toxic. $V$. angulatum was non-toxic and stimulated immunity. Use of this plant in cancer needs further investigation.

\section{Acknowledgements}

This work was financially supported by a grant from National Medicinal Plants Board, Department of AYUSH, Ministry of Health and Family Welfare, Government of India awarded to Girija Kuttan. Authors are thankful to Ms. Liji M J for helping in the preparation of manuscript and Dr. G R Shivamurthy for helping in the collection of plants used in this study as well as identification

\section{Conflict of interest}

The authors declare that no conflict of interest exists in the course of conducting this research. Both the authors had final decision regarding the manuscript and the decision to submit the findings for publication.

\section{References}

Asad, M.; Santhosh, J. and Agarwal, S. (2016). Isolation and characterization of flavan glycosides from Viscum angulatum B Heyne ex DC.and screening for hypoglycemic activity. Ann. Phytomed., 5:124-129.

Cheesbrough, M. and McArthur, J. (1976). A laboratory manual for rural tropical hospitals: A basis for training courses: English Language Book Society and Church Hill Livingston, pp:145.

Finn, O.J. (2012). Immuno-oncology: Understanding the function and dysfunction of the immune system in cancer. Annals of Oncology, 23:86-89.

Franz, H. (1986). Mistletoe lectins and A and B changes. Oncology, 43: 23-34.

Jadhav, R.B.; Bhatnagar, S.P. and Surana, S.J. (2010). Diuretic activity of squamatemistotle, Viscum angulatum. Pharm Biol., 48:417-421.

Jerne, N.K. and Nordin, A.A. (1963). Plaque formation in agar by single antibody-producing cells. Science, 140:405-405.

Jordan, E. and Wagner, H. (1986). Structure and properties of polysaccharide from Viscum album L. Oncology, 43:8-15.

Justo, G.Z.; Durán, N. and Queiroz, M.L.S. (2003). Natural killer cell activity, lymphocyte proliferation, and cytokine profile in tumor bearing mice treated with MAPA, a magnesium aggregated polymer from Aspergillusoryzae. Immunopharmacology and Immunotoxicology, 25:305-319.

Khatun, A.; Rahman, M.; Rhman, M.M.; Hossain, H.; Jahan, I.A. and Nesa, M.L. (2016). Antioxidant, antinociceptive and CNS activities of Viscum orientale and high sensitive quantification of bioactive polyphenols by UPLC. Frontiers in Pharmacology, 7:176-181.

Kuttan, G. and Kuttan, R. (1992). Immunomodulatory activity of a peptide isolates from Viscum album extract. Immun Invest., 21:285-296.

Kuttan, G; Vasudevan D.M. and Kuttan, R. (1998). Isolation and identification of a tumor reducing component from mistletoe extract (Iscador). Cancer Letters, 41:307-314.

Kuttan, R.; Shivamurthy, G.R. and Kuttan, G. (2017). Potential antitumor and anti-inflammatory activity of six mistletoe plants in the Family Viscaceae present in the Western Ghats, India. International Journal of Pharmacy and Pharmaceutical Sciences, 9:9751491.

Leroi (1975). Clinical experience with mistletoe preparation Iscador: Vittoriq Klostermann, Frankfart, pp:403-414.

Linn J.; Chiou, Y. and Lin, Y. (2002). Phenolic glycosides from Viscum angulatum. Journal of Natural Products, 65:638-640.

Murali, M.; Puneetlal, G.K.; Triveni, M.C.; Niranjan, M.H.; Shivamurthy, G.R., Niranjana, S.R.; Prakash, S.R. and Amruthesh, K.N. (2011). Phytochemical screening and antioxidant activity of hemiparasitic Indian mistletoe Viscum nepalense Sprengel. Journal of Pharmacy Research, 4:3348-3350.

Newman, D.J.; Cragg, G.M. and Snader, K.M. (2003). Natural products as sources of new drugs over the period 1981-2002. Journal of Natural Products, 66:1022-1037.

Ochwang, D.O.; Kimwele1, C.N.; Oduma, J.A.; Gathumbi, P.K.; Kiama, S.G. and Efferth, T. (2014). Phytochemical screening of medicinal plants of the Kakamega Country, Kenya: Commonly used against cancer. Medicinal and Aromatic Plants, pp:5-6.

Petrus, A.J.A. (2011). Antioxidant constitution of the mistletoe, Viscum capitallatum Smith. Asian Journal of Chemistry, 23:3014-3020.

Polu, P.; Nayanabhirama, U. and Khan, S. (2015). Herbal medicinal plants as anticancer agents. Ann. Phytomed., 4:37-45.

Samuelson, G. and Petterson, B.M. (1971). The amino acid sequence of Viscotoxin B from European Mistletoe. Eur. J. Biochem., pp:9689.

Singh, V.K.; Agarwal, S.S. and Gupta, B.M. (1984). Immunomodulatory activity of Panax ginseng extract. Planta Medica, 50:462-465.

Sredni, B.; Albeck, M.; Kazimirsky, G. and Shalit, F. (1992). The immunomodulator AS101 administered orally as a chemoprotective and radioprotective agent. International Journal of Immunopharmacology, 14:613-619.

Yuvaraj, P.; Subramoniam, A.; Louis, T.; Madhavachandran, V. and Narasu, M.L. (2013). Attenuation of expression of cytokines, oxidative stress and inflammation by hepatoprotective phenolic acids from the Spesia populnea Soland ex Correa stem bark, Ann.Phytomed., 2: 47-56.

Vayalil, P.K.; Kuttan, G. and Kuttan, R. (2002). Protective effects of Rasayanas on cyclophosphamide and radiation induced damage. The Journal of Alternative and Complementary Medicine, 8:787796.

Vayalil, P.K.; Kuttan, G. and Kuttan, R. (2002). Rasayanas: Evidence for the concept of prevention of disorders. The American Journal of Chinese Medicine, 30:155-17.

Winn, H.J. (1961). Immune mechanisms in Homo transplantation.II: Quantitative assay of immunologic activity of lymphoid cells stimulated by tumor homografts. Journal of Immunology, 86:228239.

Zammaron, B.F. and Chen, W. (2011). Dual roles of immune cells and their factors in cancer development and progression. International Journal of Biological Sciences, 7:651-658.

Citation: Girija Kuttan and Ramadasan Kuttan (2019). Immunopotentiating activity of hemiparasitic plants of family Viscaceae with special reference to Viscum angulatum Heyne ex DC.. Ann. Phytomed., 8(1):110-115. 